\title{
PENGGUNAAN PEER ASSESMENT RATING INDEX PADA EVALUASI HASIL PERAWATAN ORTODONTIK DENGAN TEKNIK BEGG
}

\author{
${ }^{1}$ Pritartha S. Anindita \\ ${ }^{2}$ Harkati Dewanto \\ ${ }^{2}$ Suparwitri
}

\author{
${ }^{1}$ Program Studi Kedokteran Gigi Fakultas Kedokteran Universitas Sam Ratulangi Manado \\ ${ }^{2}$ Bagian Ortodonsia Fakultas Kedokteran Gigi Universitas Gadjah Mada \\ Email:ps_anindita@yahoo.com
}

\begin{abstract}
The aim of orthodontic treatment is to reach the best functional and esthetic occlusion. Because there are differences of opinions among clinicians about orthodontic treatment outcomes, the evaluation of orthodontic treatment outcomes will be more accurate and objective if we apply specific criteria that can be measured. Recently, only PAR Index (Peer Assessment Rating Index) can be accepted universally as reliable and valid in order to evaluate orthodontic treatment outcomes. The aim of this study was to evaluate the outcomes of orthodontic treatment using the Begg Appliance by Peer Assessment Rating Index. The object of this study consisted of 248 pairs of dental casts that contained 124 dental casts before treatment and 124 dental casts after treatment, which information were obtained from the patient case archive of those treated with the Begg Appliance at the Orthodontic Clinical Faculty of Dentistry, Gadjah Mada University 1996-2004. Dental casts that fulfilled the requirements were measured using the PAR Ruler and then assessed using the PAR Index. Scoring was applied to each component. The score of each component was weighted, and then the difference of score was calculated before and after treatment. That represents the degree of improvement as a result of orthodontic treatment. The result revealed that PAR Index can be used to evaluate orthodontic treatment outcomes using the Begg Appliance.
\end{abstract}

Keywords: PAR Index, orthodontic treatment outcomes

\begin{abstract}
Abstrak: Tujuan perawatan ortodontik adalah mendapatkan kemungkinan oklusi terbaik secara fungsional maupun secara estetik. Terdapat beberapa hal yang menyebabkan terjadinya perbedaan antar klinisi dalam evaluasi hasil perawatan ortodontik. Oleh karena itu evaluasi ini akan lebih akurat dan objektif jika menggunakan kriteria tertentu yang dapat diukur. Dewasa ini satu-satunya indeks untuk menilai hasil perawatan ortodontik yang telah diterima secara universal, reliabel dan valid adalah PAR Index (Peer Assessment Rating Index). Tujuan penelitian adalah untuk mengukur dan menilai secara objektif penggunaan Peer Assesment Rating Index pada evaluasi hasil perawatan ortodontik dengan Teknik Begg. Objek penelitian terdiri dari 248 pasang model studi rahang atas dan bawah, yaitu 124 pasang model studi sebelum perawatan dan 124 pasang model studi sesudah perawatan. Objek penelitian diperoleh dari arsip kasus pasien yang dirawat dengan Alat Ortodontik Cekat Teknik Begg di Klinik Ortodonsia Fakultas Kedokteran Gigi Universitas Gadjah Mada Tahun 1996-2004. Model studi yang memenuhi persyaratan tersebut diukur menggunakan PAR Ruler dan kemudian dinilai menggunakan $P A R$ Index. Dilakukan penghitungan skor untuk tiap komponen, dilakukan penghitungan dengan pembobotan, kemudian dihitung selisih skor sebelum dan sesudah perawatan, yang menggambarkan derajat perbaikan dan keberhasilan perawatan ortodontik. Hasil penelitian menunjukkan bahwa PAR Index dapat digunakan untuk evaluasi hasil perawatan ortodontik dengan Teknik Begg.
\end{abstract}

Kata kunci: PAR Index, hasil perawatan ortodontik. 
Tujuan perawatan ortodontik adalah untuk memperoleh oklusi terbaik secara fungsional maupun estetik. Namun demikian seringkali terjadi perbedaan antar klinisi dalam menentukan apakah tujuan perawatan ortodontik telah tercapai dan apakah alat dapat dilepas. Beberapa penyebabnya antara lain: pendapat subjektif dan pengalaman klinisi, kemampuan, pengetahuan, dan keterampilan yang berbeda serta variasi individual sebagai akibat perawatan ortodontik. Evaluasi hasil perawatan ortodontik akan lebih akurat dan objektif jika menggunakan kriteria tertentu yang dapat diukur. ${ }^{1-6}$

Salah satu alat ortodentik cekat yang digunakan di klinik ortodensia Fakultas Kedokteran Gigi Universitas Gajah Mada adalah Tekinik Begg. Teknik Begg alat ortodentik cekat yang menawarkan sistem mekanika yang menyeluruh bagi penanganan gerakan gigi sehingga dapat digunakan untuk perawatan berbagai bentuk maloklusi, dengan maupun tanpa pencabutan.

Untuk menilai komponen-komponen yang dikoreksi oleh mekanika perawatan dengan teknik Begg digunakan PAR Index. $P A R$ Index, yang dirancang oleh Richmond dan kawan-kawan, menilai hasil perawatan ortodentik dengan membandingkan skor pra dan pasca perawatan. Evaluasi hasil perawatan dengan PAR Index membutuhkan suatu alat yang disebut $P A R$ Ruler yang berisi ringkasan informasi mengenai cara penilaian dengan PAR Index, mencerminkan isi indeks, mempermudah penilaian dengan cepat serta memungkinkan titik kontak dilihat melalui penggaris. ${ }^{7}$

Tulisan ini bermaksud menguraikan penelitian tentang penggunaan PAR Index dalam hal mengevaluasi hasil perawatan ortodentik dengan teknik Begg.

\section{TINJAUAN PUSTAKA}

Dewasa ini satu-satunya standar pengukuran hasil perawatan ortodontik yang telah diterima secara umum, dapat dipercaya dan sahih adalah PAR Index (Peer Assessment Rating Index). PAR Index dirancang oleh Richmond dan kawan-kawan untuk menilai hasil perawatan ortodontik dengan membandingkan skor pra dan pasca perawatan. Hasil perawatan yang diberi skor meliputi 5 komponen yaitu: 1) segmen anterior atas dan bawah, 2) oklusi bukal kanan dan kiri, 3) jarak gigit (overjet), 4) tumpang gigit (overbite), dan 5) garis tengah (midline). Perbedaan skor pra dan pasca perawatan menggambarkan derajat perbaikan dan keberhasilan perawatan. PAR Index pada proses penyusunannya menunjukkan reliabilitas yang baik sekali dengan koefisien korelasi inter pemeriksa sebesar 0,95 dan antar pemeriksa 0,91. PAR Index juga menunjukkan korelasi yang tinggi dengan pendapat para dokter gigi mengenai keparahan maloklusi, dengan koefisien korelasi Pearson 0,85. PAR Index menawarkan keseragaman dan standarisasi penilaian hasil perawatan ortodontik. ${ }^{2,7}$

Kemajuan hasil perawatan dinilai dalam beberapa kriteria yaitu: 1) buruk, tidak ada perubahan jika persentase perubahan kurang dari $30 \%, 2$ ) ada perbaikan jika perubahan lebih dari atau sama dengan $30 \%, 3)$ perubahan menjadi sangat baik jika terdapat perubahan skor sebesar 22 atau lebih. Derajat perbaikan hasil perawatan dapat dinilai secara objektif menggunakan nomogram. $^{7}$

Perawatan ortodontik dengan hasil yang baik dapat dicapai dengan penggunaan alat ortodontik cekat. Keunggulan alat cekat adalah: 1) kemampuan alat tersebut untuk menggerakkan gigi dalam 3 dimensi yaitu arah bukolingual, mesiodistal dan oklusoapikal, 2) memberikan retensi dan stabilisasi yang baik, 3) pengontrolan kekuatan yang efektif, 4) waktu perawatan relatif lebih singkat, 5) dapat dipakai pada kasus-kasus yang sulit serta untuk gerakan-gerakan tipping, bodily dan torque. Keberhasilan perawatan ortodontik dengan alat cekat jauh lebih baik dibandingkan dengan perawatan menggunakan alat lepasan. ${ }^{1,3,8,9}$

Alat ortodontik cekat Teknik Begg mempunyai keuntungan dan kerugian. Keuntungannya yaitu: 1) efisiensi perawatan, 2) rasa tidak nyaman dan trauma yang minimal, 3) perbaikan estetis relatif cepat, 4) kemungkinan relaps relatif kecil, dan 5) waktu perawatan relatif singkat. Kerugian 
Teknik Begg yaitu: 1) sangat membutuhkan kerjasama pasien, 2) seringkali terjadi malfungsi alat, 3) kesulitan pada tahap penyelesaian, 4) resiko memburuknya status kebersihan mulut, 5) trauma puncak alveolar (alveolar crest), 6) resiko menjadi curamnya sudut dataran mandibula, 7) pada kondisi tertentu terjadi kesulitan intrusi gigi anterior maksila, 8) flattening bibir, dan 9) teknik yang relatif kompleks. Teknik Begg menyediakan sarana yang lengkap dalam mengontrol mahkota dan posisi akar dalam tiga dataran ruang. 1,10

\section{BAHAN DAN CARA}

Objek penelitian adalah model studi rahang atas dan bawah pasien yang dirawat dengan alat ortodontik cekat Teknik Begg di Klinik Ortodonsia Fakultas Kedokteran Gigi Universitas Gadjah Mada periode 1 Januari 1996 - 31 Desember 2004. Model harus memenuhi kriteria : 1) merupakan model studi pra dan pasca perawatan, 2) model tidak rusak, dan 3) gigi-geligi tetap. Penelitian dilakukan terhadap seluruh populasi yang memenuhi persyaratan. Alat penelitian adalah $P A R$ Ruler yang berupa penggaris terbuat dari plastik tebal, berisi ringkasan kriteria skoring PAR Index. Penggaris ini diperoleh dari Basic Introductory Course Manchester University.

Dilakukan seleksi model studi pada 223 kasus pasien yang dirawat di Klinik Ortodonsia Fakultas Kedokteran Gigi UGM periode 1 Januari 1996 - 31 Desember 2004. Diperoleh 124 kasus yang memenuhi persyaratan yang terdiri atas model studi pra dan pasca perawatan. Dengan demikian terdapat 248 model studi terdiri atas 124 model pra perawatan dan 124 model pasca perawatan.

Dilakukan pengukuran pada model hasil seleksi, menggunakan PAR Ruler dan dilakukan penilaian sesuai dengan petunjuk penilaian PAR Index. Pengukuran dilakukan oleh peneliti sendiri sebanyak tiga kali untuk tiap-tiap item, kemudian diambil reratanya. Pengukuran meliputi segmen anterior atas dan bawah; oklusi bukal kanan dan kiri yang meliputi pengukuran antero- posterior, transversal, dan vertikal; pengukuran jarak gigit meliputi jarak gigit positif dan gigitan silang anterior, pengukuran tumpang gigit dan gigitan terbuka anterior; pengukuran garis tengah.

Dilakukan skoring pada hasil pengukuran. Hasil skoring dihitung pembobotannya sesuai dengan tabel. Dilakukan penghitungan jumlah total skor pra dan pasca perawatan. Dilakukan penghitungan selisih skor untuk masing-masing kasus pra dan pasca perawatan. Hasil penghitungan untuk seluruh kasus dimasukkan pada tabel kemudian dihitung reratanya. Data hasil penelitian dikelompokkan dengan ketentuan: 1) jika skor pra perawatan $\geq 22$ selisih dihitung berdasarkan berkurangnya skor, 2) jika skor pra perawatan $<22$ selisih dihitung dalam persen. Data hasil penelitian dikelompokkan menurut jenis komponen yang diukur, dan dikelompokkan menurut klasifikasi Maloklusi Angle. Data hasil penelitian selanjutnya dituangkan dalam nomogram.

\section{HASIL DAN PEMBAHASAN}

Hasil penelitian yang dikelompokkan menurut tingkat keparahan maloklusi menunjukkan sebaran pada empat kelompok (tabel 1). Tidak ada subyek masuk pada kelompok oklusi ideal, maloklusi ringan sebesar 26 subyek $(33,61 \%)$, maloklusi sedang $77(62,11 \%)$, maloklusi parah 12 $(9,9 \%)$, maloklusi sangat parah $2(1,61 \%)$. Pasca perawatan memperlihatkan sebaran hanya pada dua kelompok yaitu kelompok oklusi ideal sebanyak 68 subjek $(54,84 \%)$ dan maloklusi ringan 56 subjek $(45,16 \%)$.

Tabel 2 menunjukkan 69 subjek $(55,65 \%)$ memiliki skor perawatan $<22$ de-ngan rerata persentase pengurangan skor $92,78 \pm 12,32$ masuk kriteria perubahan men-jadi sangat baik. Lima puluh lima subjek $(44,35 \%)$ memiliki skor $\geq 22$ dengan rerata pengurangan skor $28,53 \pm 7,13$ juga menunjukkan perubahan menjadi sangat baik. Rerata skor pra perawatan pada Tabel 3 adalah 22,51 \pm 8,87 masuk kriteria maloklusi sedang. Rerata skor pasca perawatan mendekati skor 22 menunjukkan ada perbaikan mendekati kriteria perubahan 
Tabel 1. Distribusi subjek menurut keparahan maloklusi pra dan pasca perawatan

\begin{tabular}{cccccc}
\hline Skor PAR Index & Maloklusi & Pra & \% & Pasca & $\%$ \\
\hline 0 & Ideal & 0 & 0 & 68 & 54,84 \\
$1-16$ & Ringan & 33 & 26,61 & 56 & 45,16 \\
$17-32$ & Sedang & 77 & 62,11 & 0 & 0 \\
$33-48$ & Parah & 12 & 9,67 & 0 & 0 \\
$>48$ & Sangat parah & 2 & 1,61 & 0 & 0 \\
Total & & 124 & 100 & 124 & 100 \\
\hline
\end{tabular}

Tabel 2. Rerata pengurangan skor dan rerata persentase pengurangan skor pada maloklusi dengan skor pra perawatan $<22$ dan $\geq 22$

\begin{tabular}{ccccc}
\hline Skor awal & Jumlah & $\%$ & $\begin{array}{c}\text { Rerata } \\
\text { pengurangan } \\
\text { skor }\end{array}$ & $\begin{array}{c}\text { Rerata \% } \\
\text { pengurangan } \\
\text { skor }\end{array}$ \\
\hline$<22$ & 69 & 55,65 & - & $92,78 \pm 12,32$ \\
$\geq 22$ & 55 & 44,35 & $28,53 \pm 7,13$ & - \\
\hline
\end{tabular}

menjadi sangat baik Persen-tase selisih skor sebesar 93,42 \pm 10,92 juga menunjukkan perubahan menjadi sangat baik.

Tabel 3. Rerata dan simpangan baku skor pra perawatan, pasca perawatan, pengurangan skor, dan pengurangan skor dalam $\%$.

\begin{tabular}{lr}
\hline & \multicolumn{1}{c}{ X+SD } \\
\hline Pra perawatan & $22,51 \pm 8,87$ \\
Pasca perawatan & $1,42 \pm 2,32$ \\
$\begin{array}{l}\text { Pengurangan skor } \\
\begin{array}{l}\text { Pengurangan skor } \\
\text { dalam \% }\end{array}\end{array}$ \\
\hline
\end{tabular}

Presentase hasil perawatan yang tinggi pada penelitian ini disebabkan oleh beberapa hal. Subjek penelitian seluruhnya memakai alat cekat pada rahang atas maupun bawah sehingga memungkinkan tercapainya kesejajaran gigi-geligi dan hasil perawatan yang ideal. Semua subjek berasal dari kasus yang telah dinyatakan selesai perawatan dan masuk pada periode retainer. Subjek penelitian dirawat oleh karyasiswa yang sedang menjalani pendidikan spesialis ortodonsia sehingga semua kasus diupayakan mencapai hasil ideal.

Kemungkinan lain sehingga diperoleh skor pengurangan yang besar adalah pem- bobotan untuk masing-masing komponen. Subjek penelitian sebagian besar adalah kasus maloklusi Angle Kelas II yang biasanya memiliki ciri jarak gigit yang besar. Bobot jarak gigit yang besar yaitu 6 menyebabkan skor pra perawatan untuk jarak gigit menjadi besar, sedangkan jarak gigit dapat dikoreksi dengan mudah menggunakan Teknik Begg sehingga pada akhir perawatan tercapai jarak gigit ideal. Hal tersebut memberikan pengaruh yang besar terhadap pengurangan skor secara keseluruhan.

Tabel 4. Data rerata dan simpangan baku skor pra dan pasca perawatan masing-masing komponen

\begin{tabular}{lcc}
\hline \multicolumn{1}{c}{ Komponen } & Pra & Pasca \\
\hline Segmen anterior & $9,47 \pm 3,18$ & $0,04 \pm 0,02$ \\
Oklusi bukal & $3,01 \pm 2,38$ & $0,60 \pm 0,94$ \\
Jarak gigit & $5,56 \pm 3,52$ & 0,00 \\
Tumpang gigit & $1,23 \pm 1,55$ & 0,00 \\
Garis tengah & $3,48 \pm 2,44$ & $0,71 \pm 1,84$ \\
\hline
\end{tabular}

Komponen oklusi bukal sebaliknya merupakan faktor yang relatif sulit dikoreksi, tetapi dengan nilai pembobotan yang kecil yaitu 1, pengaruh nilai komponen tersebut terhadap skor secara keseluruhan menjadi kecil pula. ${ }^{3,10,11}$ 
Skor pasca perawatan $0,04 \pm 0,02$ untuk komponen segmen anterior menunjukkan masih ada displacement, berarti masih dijumpai gigi berjejal ringan pada akhir perawatan. Skor pasca perawatan oklusi bukal sebesar 0,60 $\pm 0,94$ menunjukkan masih terdapat interdigitasi yang kurang sempurna pada gigi-gigi posterior. Komponen jarak gigit dan tumpang gigit mencapai hasil ideal pada akhir perawatan $(0,00)$, berarti koreksi jarak gigit dan tumpang gigit sempurna. Skor komponen garis tengah menunjukkan angka paling tinggi dibandingkan komponen lain yaitu $0,71 \pm 1,84$. Keadaan tersebut menunjukkan bahwa pada akhir perawatan beberapa kasus tidak mencapai garis tengah yang segaris antara rahang atas dan rahang bawah.

Validasi untuk menentukan pembobotan dilakukan oleh ortodontis di Inggris dengan sampel orang Inggris yang termasuk dalam ras Kaukasoid dengan profil yang berbeda dengan kebanyakan orang Indonesia yang termasuk ras Mongoloid. Perbedaan persepsi subjektif kaitannya dengan profil yang dipengaruhi oleh ras serta peran masing-masing komponen dalam membentuk maloklusi kemungkinan dapat memberikan perbedaan bobot. American Board of Orthodontic telah menyusun standar pembobotan yang berbeda dengan pendapat para ortodontis di Inggris. Di Indonesia kemungkinan dapat juga dilakukan studi validasi untuk menentukan bobot masing-masing komponen yang sesuai untuk profil Indonesia. $^{2}$

Standar penilaian oklusi bukal pada $P A R$ Index yang memberikan skor nol pada subkomponen anteroposterior pada keadaan maloklusi baik untuk kelas I, II dan III memungkinkan skor hasil perawatan maloklusi Kelas II mendekati ideal, bahkan ideal pada Kelas III.. Keadaan tersebut sebenarnya kurang tepat jika dicocokkan pada tujuan perawatan Teknik Begg. Begg \& Kesling menyatakan bahwa tahap 1 mekanika perawatan dengan Teknik Begg pada kasus Kelas III meliputi overkoreksi relasi oklusi anteroposterior hingga mencapai relasi mendekati Kelas II. Fletcher dengan tegas menyatakan bahwa salah satu tujuan yang akan dicapai pada tahap1 adalah relasi bukal Kelas 1. Maloklusi Kelas II dan III tipe skeletal kemungkinan besar hasil perawatannya tidak akan mencapai ideal, karena koreksi dengan alat cekat sekalipun hanya akan mengubah relasi dental, kecuali dilakukan kombinasi perawatan bedah. ${ }^{3,11}$

Data menurut klasifikasi maloklusi Angle (Tabel 5) menunjukkan skor pra perawatan pada ketiga kelompok maloklusi ada pada kelompok maloklusi ringan. Skor pasca perawatan pada kelas I mendekati ideal $(1,29 \pm 2,12)$ pada kelas II juga men-dekati ideal $(1,68 \pm 2,59)$ dan pada maloklusi kelas III ideal $(0,00)$. Maloklusi kelas I dan kelas III Angle perubahannya menjadi sangat baik karena lebih dari 30\% (92,16+12,90\% dan $98,33 \pm 2,67 \%)$. Pengurangan skor pada maloklusi Angle kelas II sebesar 22,84 juga menunjukkan perubahan menjadi sangat baik karena lebih dari 22 skor.

Tabel 6 memperlihatkan bahwa tidak ada subyek masuk dalam kriteria buruk atau tidak ada perubahan. Subyek dengan kriteria ada perbaikan sejumlah 77 orang $(62,10 \%)$ dan subyek dengan kriteria perubahan menjadi sangat baik sejumlah 47 . Nomogram hasil penelitian dapat dilihat pada Gambar 1.

Tabel 5. Rerata dan simpangan baku skor pra perawatan, pasca perawatan, pengurangan skor dan pengurangan skor dalam persentase (\%) berdasarkan klasifikasi maloklusi Angle

\begin{tabular}{lcrcc}
\hline \multirow{2}{*}{ Jumlah kasus $(\%)$} & Kelas I & Kelas II & Kelas III \\
\cline { 2 - 5 } & \multicolumn{1}{c}{$\mathbf{3 5 ( 2 8 , 2 3 \% )}$} & $\mathbf{7 3 ( 5 8 , 8 7 \% )}$ & $\mathbf{1 6 ( 1 2 , 9 0 \% )}$ \\
\hline Pra perawatan & $19,23 \pm 6,69$ & $24,52 \pm 9,85$ & $20,50 \pm 5,32$ \\
Pasca perawatan & $1,29 \pm 2,12$ & $1,68 \pm 2,59$ & 0,00 \\
Pengurangan skor & - & $22,84 \pm 9,46$ & - \\
Pengurangan skor \% & $92,16 \pm 12,90$ & - & $98,33 \pm 2,67$ \\
\hline
\end{tabular}


Tabel 6. Derajat perbaikan hasil perawatan KEdasarkan nomogram

\begin{tabular}{lcc}
\hline \multicolumn{1}{c}{ Derajat perbaikan } & Jumlah & $\mathbf{\%}$ \\
\hline Buruk/ tidak ada perubahan & 0 & 0 \\
Ada perbaikan & 77 & 62,10 \\
Sangat bertambah baik & 47 & 37,90 \\
\hline
\end{tabular}

Nomogram memperlihatkan sebagian besar subyek sebarannya terletak atau mendekati garis paling bawah, berarti mendekati angka nol atau hasil perawatan yang ideal. Skor pra perawatan terendah adalah 9 , sedangkan skor pra perawatan tertinggi 56. Skor pasca perawatan terendah adalah 0 , dan skor pasca perawatan tertinggi 11 . Beberapa subyek memiliki skor awal dan akhir sama sehingga terletak pada koordinat yang sama. Sembilan subyek bahkan memiliki skor sama yaitu 20 pada awal perawatan, dan 0 pada akhir perawatan.

\section{KESIMPULAN DAN SARAN}

\section{Kesimpulan}

Dari hasil ini penelitian dapat disimpulkan bahwa PAR Index dapat digunakan untuk mengevaluasi hasil perawatan ortodontik dengan Teknik Begg.

\section{Saran}

Berdasarkan hasil penelitian ini maka:

1. Dianjurkan memakai PAR Index untuk menilai evaluasi hasil perawatan ortodontik di klinik-klinik maupun praktek pribadi.

2. Disarankan melakukan studi validasi $P A R$ Index untuk menentukan bobot masing-masing komponen yang sesuai untuk profil Indonesia.

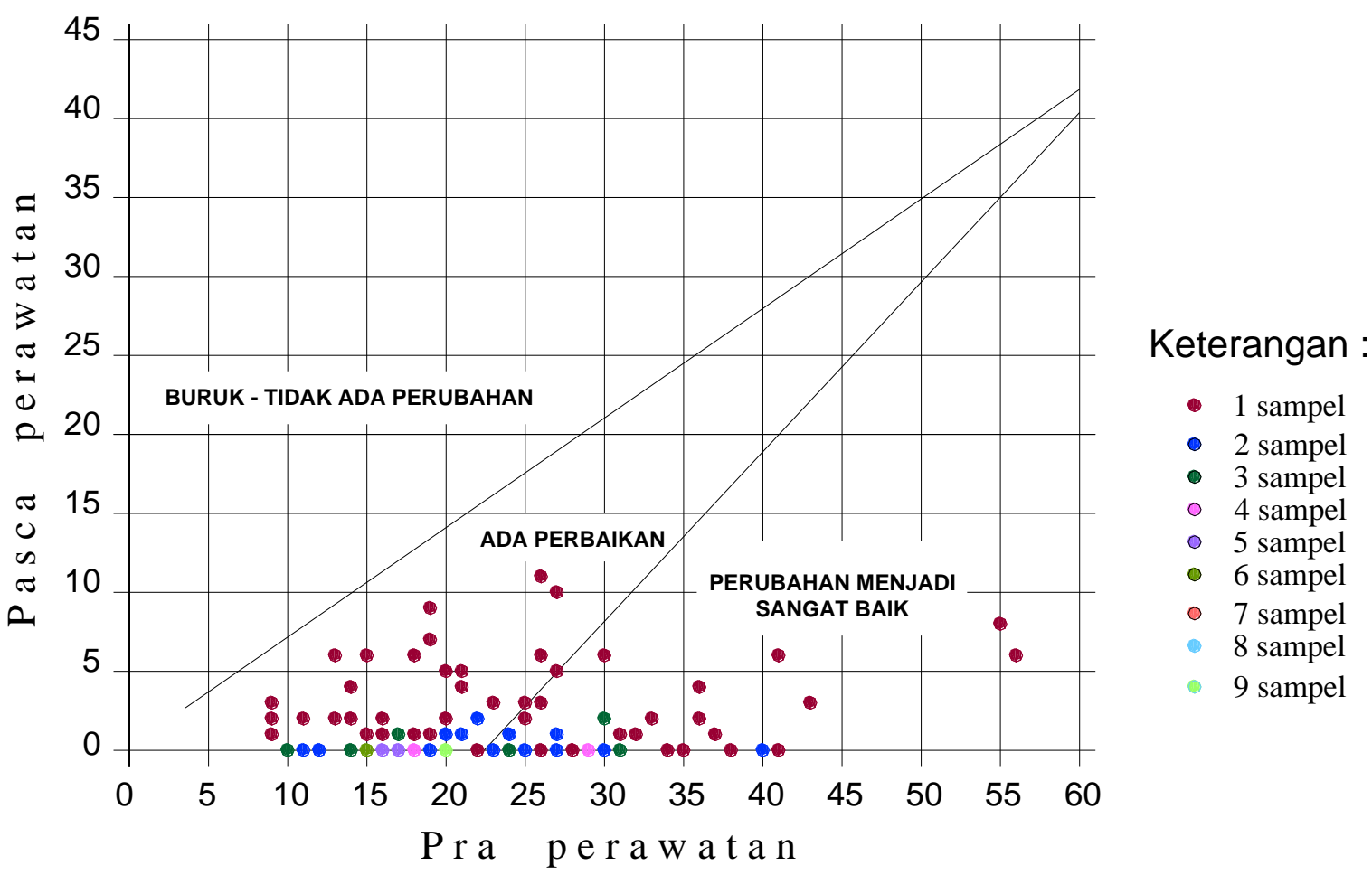

Gambar 1. Nomogram hasil penelitian 


\section{DAFTAR PUSTAKA}

1. Proffit WR. Contemporary Orthodontics, 3th ed. St. Louis: CV Mosby Co, 2000; p. 385-8.

2. Dyken RA, Sadowsky PL and Hurst D. Orthodontic Outcomes Assessment Using the Peer Assessment Rating Index, Angle Orthod. 2001;:71(3):164-169.

3. Begg PR and Kesling PC. 1977, Begg Orthodontic Theory and Technique, $3^{\text {rd }}$ ed. Philadelphia: WB Saunder Co, 1977; p. 87-9.

4. Shaw WC, Richmond S and O'Brien KD. The Use of Occlusal Indices: A European Perspective. Am J Orthod Dentofac Orthop. 1995;107(1):1-10.

5. Guzman LD, Bahirael D, Weyant RJ and O'Brien K. The Validation of the Peer Assessment Rating Index for Maloclusion Severity and Treatment Difficulty. Am J Orthod Dentofac Orthop. 1995; 107(2):172-176.

6. Rahardjo P. Hasil Perawatan Ortodontik dengan Peranti Cekat Dinilai dengan
PAR Index. Majalah Ortodontik. 2001;1(1):15-17.

7. Richmond S, Shaw WC, O'Brien KD, Buchanan IB, Jones R, Stephens CD, et al. The Development of the PAR Index (Peer Assessment Rating): Reliability and Validity. Eur J Orthod. 1992; 14(2):125-139.

8. Firestone $\mathbf{A R}$, Hsler $\mathbf{R U}$ and Ingervall $B$. Treatment results in dental school orthodontic patients in 1983 and 1993, Angle Orthod. 1999;69(1):19-26.

9. Richmond S, Shaw WC, Roberts CT and Andrews M. The PAR Index (Peer Assessment Rating): methods to determine outcome of orthodontic treatment in terms of improvement and standards. Eur J Orthod. 1992;14(3):180-187

10. Cadmann GR. A Vade Mecum for The Begg Technique: Technical Principles. Am J Orthod. 1975;67(5):481-2.

11. Fletcher GGT. The Begg Appliance and Technique. Bristol: Wright P.S.G, 1981; p. $1-10$. 